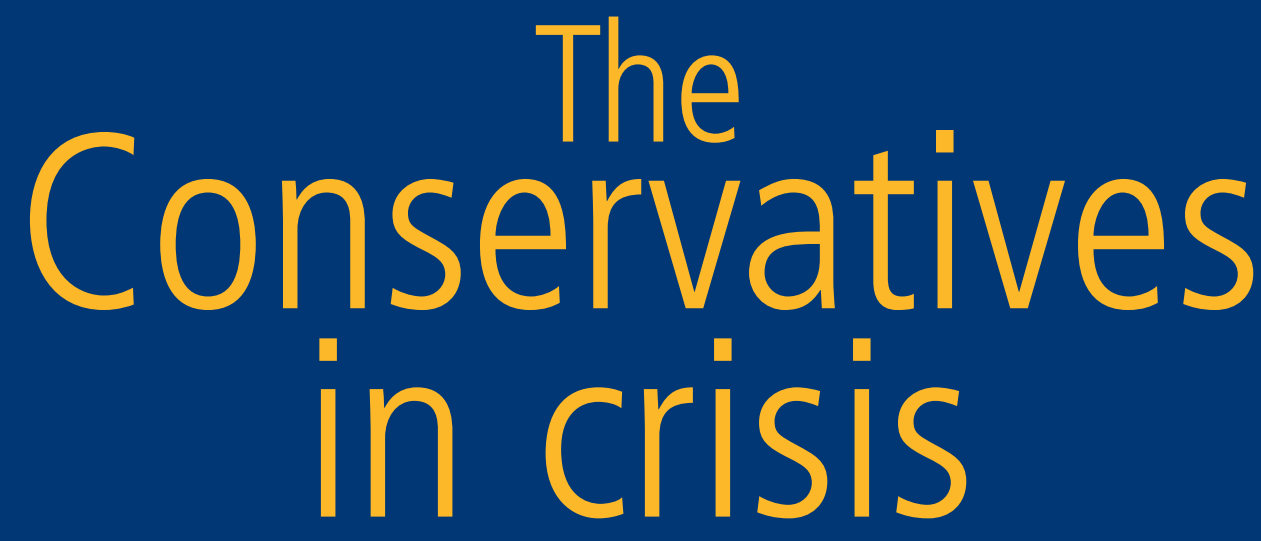

edited by Mark Garnett and Philip Lynch
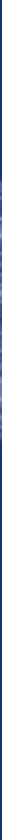

$\stackrel{+}{+}$

ㄷ

กั ก

<. స్.

곡

능

吕

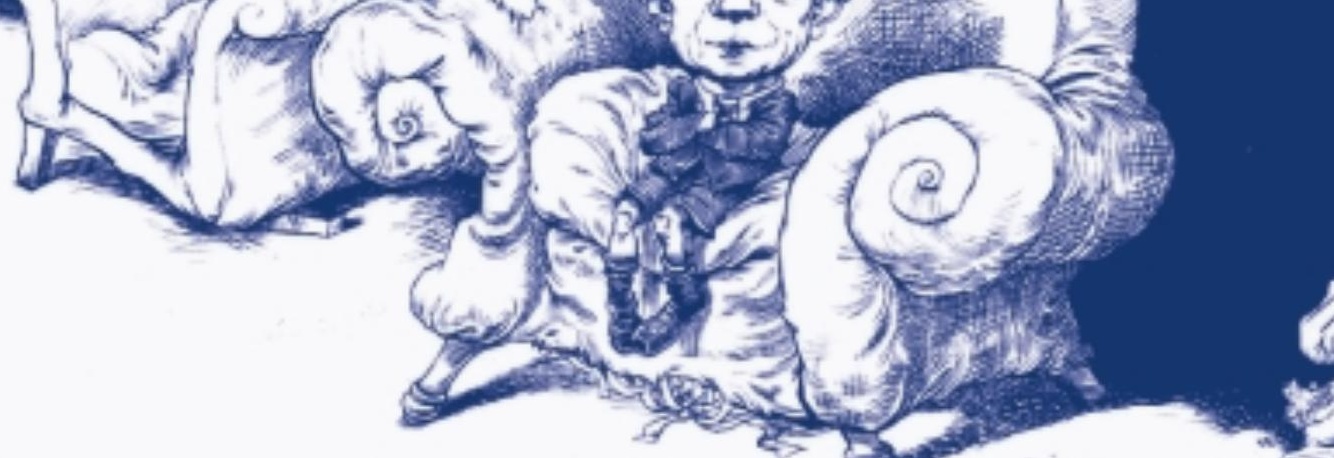




\section{THE CONSERVATIVES}

\section{IN CRISIS}

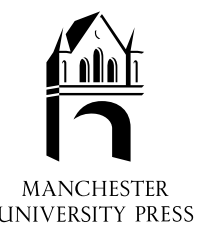


In memory of Martin Lynch 


\section{THE CONSERVATIVES IN CRISIS}

\section{The Tories after 1997}

edited by Mark Garnett and Philip Lynch

Manchester University Press

Manchester and New York

distributed exclusively in the USA by Palgrave 
Copyright (C) Manchester University Press 2003

While copyright in the volume as a whole is vested in Manchester University Press, copyright in individual chapters belongs to their respective authors, and no chapter may be reproduced wholly or in part without the express permission in writing of both author and publisher.

Published by Manchester University Press Oxford Road, Manchester M13 9NR, UK and Room 400, 175 Fifth Avenue, New York, NY 10010, USA www.manchesteruniversitypress.co.uk

Distributed exclusively in the USA by Palgrave, 175 Fifth Avenue, New York, NY 10010 , USA

Distributed exclusively in Canada by

UBC Press, University of British Columbia, 2029 West Mall, Vancouver, BC, Canada v6T 1 Z2

British Library Cataloguing-in-Publication Data

A catalogue record for this book is available from the British Library

Library of Congress Cataloging-in-Publication Data applied for

ISBN 0719063302 hardback

o 71906331 o paperback

First published 2003

$\begin{array}{lllllllllllllllllll}11 & 10 & 09 & 08 & 07 & 06 & 05 & 04 & 03 & 10 & 9 & 8 & 7 & 6 & 5 & 4 & 3 & 2 & 1\end{array}$

Typeset in Monotype Bell by

Carnegie Publishing Ltd, Chatsworth Road, Lancaster

Printed in Great Britain

by CPI, Bath 